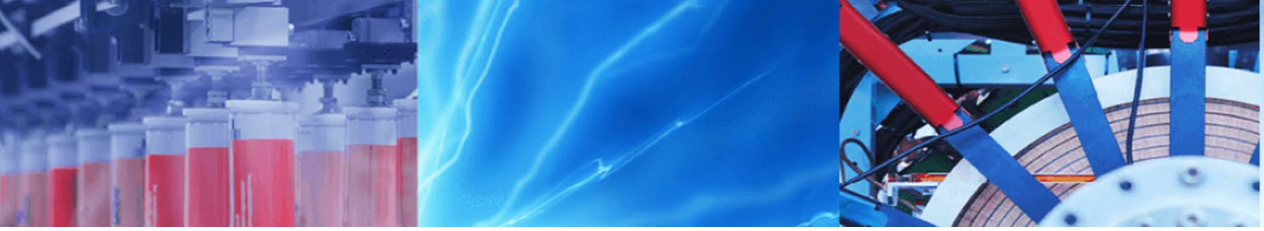

Research Article

\title{
Application of Box-Behnken design for the optimization of cellulase production under solid-state fermentation
}

\author{
Nitin Verma ${ }^{1} \cdot$ Vivek Kumar $^{1}$
}

Received: 26 September 2019 / Accepted: 23 November 2019 / Published online: 30 November 2019

(c) Springer Nature Switzerland AG 2019

\begin{abstract}
Lignocellulosic biomass offers an encouraging possibility to satisfy future energy demand since it is an abundant and potential carbon source for the production of a wide range of fuels and value-added chemicals. Most of the proposed processes are currently unable to make economically viable conversion due to incomplete utilization of the biomass feedstock. Optimization of significant process conditions plays a very crucial role in the development of efficient and cost-effective bioconversion processes. The present paper describes the Box-Behnken design based optimization to evaluates the effect of process parameters. A set of combinations of parameter viz. temperature $\left(30^{\circ} \mathrm{C}\right), \mathrm{pH}(5)$, inoculum dosages $(0.56 \mathrm{~g} / \mathrm{L})$, particle size $(850 \mu \mathrm{m})$, moisture percentage $(76)$ and incubation period (6 days) was found quite effective on cellulase production by Aspergillus niger under wheat bran based solid-state fermentation. It also evaluates the utility of dairy industry waste (whey) and starch hydrolysates in cellulase production.
\end{abstract}

Keywords Wheat bran · Box-Behnken design $\cdot$ Whey $\cdot$ Starch hydrolysates

\section{Introduction}

Lignocellulosic biomass appears to be the most promising, economical and highly renewable natural resource in the world and it serves as prominent and sustainable feedstocks for bioconversion [1, 2]. Lignocellulosic biomass mostly refers to agricultural post-processing residues such as wheat bran, rice straw, wheat straw, bagasse [3-6]. India is an agricultural land that produced a large magnitude of lignocellulosic wastes which can be utilized for the production of value-added products such as industrial enzymes or enzyme-based products. Renewable resources handle the global energy crises in a sustainable and ecofriendly manner. However, extensive research is required for the commercialization of lignocellulose mediated biotransformation process $[7,8]$.

Wheat bran is separated from the wheat kernel by the milling process and chemically it consists of cellulose and hemicellulose polysaccharides (approximately 38\%), starch (approximately 19\%), protein (approximately 18\%) and lignin (approximately $6 \%$ ). It also contains a significant amount of phenolic acids such as ferulic and $p$-coumaric acid [9-11]. It is envisaged that the utilization of both starch and hemicellulosic/cellulosic part of wheat bran would greatly expedite potential applications in lignocellulosic biomass utilization. It has also been considered as a good supporting substrate probably due to the presence of various available nutrients, good porosity, suitable particle size and consistency required for fungal anchorage and enzyme excretion $[3,5]$. Its texture remains loose in moist conditions, thereby provides a large surface area with increased water holding capacity [12]. Wheat bran serves as an excellent carbon source without any supplementary carbon or nitrogen source for the production of lignocellulolytic enzymes. The presence of starch, protein, and soluble oligosaccharides improves its microbial utilization.

Nitin Verma, nitiniit2008@gmail.com | 'Department of Paper Technology, Indian Institute of Technology, Roorkee, Saharanpur Campus, Saharanpur, U.P. 247001, India. 
The soluble cello-oligosaccharides compositions of wheat bran were proved to be one of the most significant factors for cellulase production and it can also be utilized without any prior pretreatment $[3,13]$.

Various approaches in response surface methodology (RSM) have been employed for screening and optimization of different process parameters during the fermentation process [14]. Experimental design based statistical tools is the most recent approaches in bioprocess optimization. Response surface methodology (RSM) is an assortment of mathematical and statistical tools, used for designing experiments and achieving optimum conditions of independent variables/factors for desirable responses [15, 16]. RSM based on Box-Behnken experimental design has been widely used in various bioprocess experiments to optimize process parameters $[16,17]$. Whey is a liquid by-product of the dairy industry that remains after the manufacturing process of cheese, chhana, paneer and casein. It is a serious pollutant and imposes a very high BOD of 30,000-50,000 mg/L. Discarding of whey creates a significant loss of potential nutrients and energy. On the other hand, it has also been noticed seriously by the environmentalists, due to its potent polluting strength. The bioconversion of lactose sugar present in whey to valuable products has been actively explored and could be served as a substrate for fermentation [18-20].

The key carbohydrate reserve in plants is starch (a polymer of glucose) composed of two main fractions, amylose and amylopectin. Amylose is highly hydrophilic, due to containing more hydroxyl groups. Dextrin is the intermediate product of acidic or enzymatic hydrolysis process. The starch molecule initially breaks into shorter glucose units (oligosaccharides) and further broken down into maltose and finally maltose breaks into glucose [21, 22]. The amylose content of the starch granules varies with starch sources. It has also been observed that large potato starch granules have a higher amylose content than small granules [23].

Starch utilization is widely used as an ingredient for the food and pharmaceutical industry, especially for the food industry, as substitutes, mixtures, thickening agents, and fillers [22]. It has been demonstrated that granuler size of rice starch was significantly smaller than that of the corn starch. Wheat starch shows physical and chemical properties different from potato starch. It contains higher amounts of fat mainly lysophospholipids forming gelatinous complexes with amylose, proteins and arabinoxylans [24].

The present paper portrays the Box-Behnken design based optimization of different process parameters such as temperature, $\mathrm{pH}$, moisture percentage, particle size, inoculum dosages and incubation period for cellulase production by Aspergillus niger under wheat bran based solid-state fermentation. It also describes the utility of dairy industry waste (whey) and various starch hydrolysates in cellulase induction and production process.

\section{Materials and methods}

Chemicals and reagents used to conduct the experimental work were of Himedia, Sigma Aldrich, and Merck make. Aspergillus niger NCIM 777 was procured from National Chemical Laboratory, Pune, India. Wheat bran was collected from the local market. Separate sets of batch experiment were performed in $250 \mathrm{~mL}$ Erlenmeyer flasks containing sieved wheat bran biomass, which was impregnated with the following production media in $(\mathrm{g} / \mathrm{L})$ Urea, 0.3; $\left(\mathrm{NH}_{4}\right)_{2} \mathrm{SO}_{4}, 1.4 ; \mathrm{KH}_{2} \mathrm{PO}_{4}, 2.0 ; \mathrm{MgSO}_{4} \cdot 7 \mathrm{H}_{2} \mathrm{O}, 0.3$; Peptone, 1.0; Tween 80, 0.2; $\mathrm{FeSO}_{4} \cdot 7 \mathrm{H}_{2} \mathrm{O}, 0.005 ; \mathrm{MnSO}_{4} \cdot 7 \mathrm{H}_{2} \mathrm{O}, 0.0016$; $\mathrm{ZnSO}_{4} \cdot 7 \mathrm{H}_{2} \mathrm{O} ; 0.0014 ; \mathrm{CaCl}_{2} \cdot 2 \mathrm{H}_{2} \mathrm{O} ; \mathrm{CoCl}_{2} \cdot 6 \mathrm{H}_{2} \mathrm{O}, 0.02$. Basal salt media soaked wheat bran beds were autoclaved, cooled and then inoculated with a specific volume of liquid A. niger pellets. Based on different sets of combinations of process parameters, the production flasks were placed in an incubator. Another set of batch experiments was also performed to investigate the effect of whey and starch hydrolysates. Each wheat bran bed containing production flasks inoculated with culture solution to study the effect of whey and starch hydrolysates were placed in an incubator at optimized conditions.

\subsection{Experimental design}

To optimize different process parameters for cellulase production, Box-Bhenken Design (BBD) was used for optimization work. Three different levels were studied for each independent variable. A total of 13 experiments (Different sets of combinations) were conducted for three independent variables and cellulase activity obtained in terms of FPase (IU/mL) was taken as a dependent variable (Y1). Design based experiments were performed in $250 \mathrm{~mL}$ Erlenmeyer flask containing wheat bran biomass as a solid bed. The independent variables used were process temperature $\left({ }^{\circ} \mathrm{C}\right)(X 1)$, process $\mathrm{pH}(X 2)$, inoculum dosages $(X 3)$ and their levels were mentioned in Table 2. After getting the optimized process conditions, another trail was run of 13 experiments with other three independent variables. Now the independent variables used in the trail were particle size of wheat bran $(\mu \mathrm{m})(X 1)$, moisture percentage $(X 2)$, the incubation period $(X 3)$ and their levels were mentioned in Table 5. The relation between independent and dependent variables was illustrated by the following equation. 


$$
\begin{aligned}
Y 1= & \beta 0+\beta 1 X 1+\beta 2 X 2+\beta 3 X 3+\beta 11 X 1+\beta 22 X 2 \\
& +\beta 33 X 3+\beta 12 X 1 X 2+\beta 13 X 1 X 3+\beta 23 \times 2 X 3
\end{aligned}
$$

$Y 1$ was the response; $X 1, X 2$ and $X 3$ were the independent variables; $\beta 0$ was the intercept; $\beta 1, \beta 2$ and $\beta 3$ were linear coefficients; $\beta 11, \beta 22$ and $\beta 33$ were square coefficients; and $\beta 12, \beta 13$ and $\beta 23$ were interaction coefficients.

\subsection{Preparation of starch hydrolysates}

Acid pretreatment of starch was carried out by using $2 \%$, $5 \%$, and $10 \% \mathrm{HCl}(\mathrm{v} / \mathrm{v})$ solution. $10 \mathrm{~g}$ of wheat, potato and rice starch powdered biomass were taken separately, further $40 \mathrm{~mL}$ of diluted $\mathrm{HCl}$ solution with specific strength was added to maintain the slurry of about $25 \%$. Afterwards, starch slurries were subjected to steam treatment under a pressure of $15 \mathrm{psi}$ at $121^{\circ} \mathrm{C}$ for $1 \mathrm{~h}$ and $3 \mathrm{~h}$ time duration. The treated starch slurries were used in the production medium as pure hydrolyzates.

\subsection{Lactose analysis}

The lactose content of whey was estimated by the spectrophotometric method [25]. The absorbance of the sample was determined at $540 \mathrm{~nm}$.

\subsection{Inoculum development}

Aspergillus niger NCIM 777 was procured from National Chemical Laboratory (NCL), Pune, India. For inoculum development separate experiments were performed in $250 \mathrm{~mL}$ Erlenmeyer flasks containing $100 \mathrm{~mL}$ of potato dextrose broth (PDB) medium (In $\mathrm{g} / \mathrm{L}$ peeled potato, 200; dextrose, 20; and yeast extract, 0.1 ) in which 5 loopfull cultures of Aspergillus spores were added and shaken at $180 \mathrm{rpm}$ at $30^{\circ} \mathrm{C}$ in an incubator shaker for 3 to 4 days [26]. A definite volume of prepared cultures in broth suspension was used as inoculum for further production studies.

\subsection{Dry weight determination}

The cell dry weight of Aspergillus suspensions was determined by the procedure used by Verma et al. [4]. The determination of fungal growth by cell dry weight was expressed as the mean of three independent readings.

\subsection{Preparation of production media}

Three types of production medium were used for production studies. (1) Normal basal salt media was used for production studies having the following constituents (g/L): urea, 0.3; $\left(\mathrm{NH}_{4}\right)_{2} \mathrm{SO}_{4}, 1.4 ; \mathrm{KH}_{2} \mathrm{PO}_{4}, 2.0 ; \mathrm{MgSO}_{4} \cdot 7 \mathrm{H}_{2} \mathrm{O}$, 0.3; peptone, 1.0; Tween 80, 0.2; $\mathrm{FeSO}_{4} \cdot 7 \mathrm{H}_{2} \mathrm{O}, 0.005$;
$\mathrm{MnSO}_{4} \cdot 7 \mathrm{H}_{2} \mathrm{O}, 0.0016 ; \mathrm{ZnSO}_{4} \cdot 7 \mathrm{H}_{2} \mathrm{O} ; 0.0014 ; \mathrm{CaCl}_{2} \cdot 2 \mathrm{H}_{2} \mathrm{O}$; $\mathrm{CoCl}_{2} \cdot 6 \mathrm{H}_{2} \mathrm{O}, 0.02$. (2) Modified basal salt media, In which 15,30 and $50 \%(\mathrm{v} / \mathrm{v})$ whey were incorporated in the earlier described production media separately. (3) Modified basal salt media, in which 2 and $5 \%(\mathrm{v} / \mathrm{v})$ dosages of 2 and $5 \% \mathrm{HCl}$ treated potato, wheat and rice starch hydrolysates solution were incorporated in the earlier described production media separately.

\subsection{Preparation of raw material}

Wheat bran biomass was dried then ground and sieved with a mesh screen. The ground raw material was used as a solid substrate for cellulase production studies.

\subsection{Solid state fermentation process}

A separate set of fermentation experiments was carried out in $250 \mathrm{~mL}$ Erlenmeyer flasks containing sieved wheat bran as the carbon source, which was impregnated with the earlier discussed production medium. Raw material soaked with normal as well as modified basal salt medium was autoclaved, cooled, and then inoculated with a specific volume of PD broth culture solution of $A$. niger, after that the autoclaved and inoculated flasks were placed in an incubator.

\subsection{Extraction and assay of enzyme}

For the extraction of the crude enzyme, distilled water was added to the fermented samples (in a 1:5 proportion) in Erlenmeyer flasks, and the extraction was done after shaking in a shaker at $150 \mathrm{rpm}$ for $1 \mathrm{~h}$. The sample was then filtered and the extract obtained was centrifuged at $6000 \mathrm{rpm}$. The resulting supernatant was stored and used as a crude enzyme source. All extractions were conducted in duplicate.

\subsection{Total cellulase activity (filter paper activity) and CMCase activity}

Filter paper (FPA) and carboxymethyl cellulase (CMCase) activity were determined by the method recommended by Ghose [27].

\section{Results and discussion}

\subsection{Utilization of wheat bran biomass in cellulase production}

Wheat bran due to its nutritional content and large surface area serves to be an excellent carbon source without any 
supplementary carbon source for the production of lignocellulolytic enzymes [13]. XRD and FTIR pattern of wheat bran also suggest that cellulose present in wheat bran is easily available for microbial attack. A lower percentage of lignin may also provide a fruitful conditions for the easier uptake of cellulose and other inducers required for cellulase production [28].

Separate sets of batch experiments were performed for the cellulase production studies by A. niger. Aspergillus grew well in a wheat bran based solid bed as observed in Fig. 1b.

To study the magnified view of Aspergillus growth under wheat bran bed, scanning electron microscopic studies of Aspergillus treated wheat bran sample were carried out. Wheat bran bed had both rough and smooth types of surfaces with layered structural morphology as shown in the

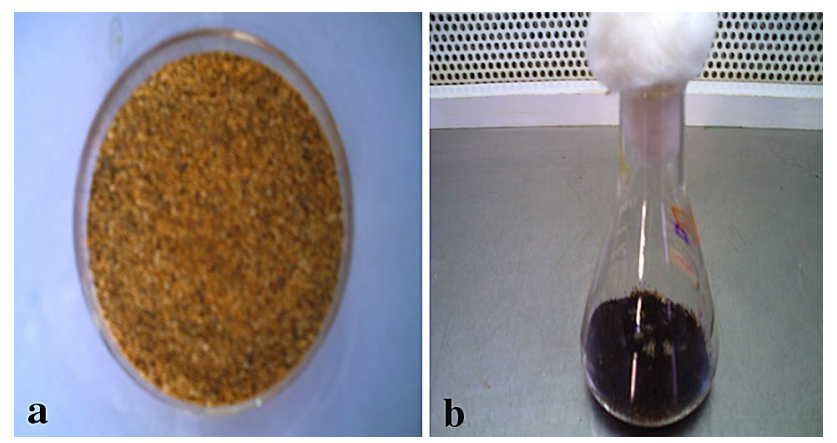

Fig. 1 Grounded and sieved wheat bran (a), growth of Aspergillus under wheat bran solid bed (b)
SEM micrograph (Fig. 2a). The magnified view of Aspergillus treated wheat bran bed is shown by SEM micrograph (Fig. 2b, c). Vast microbial growth was observed at the surface of raw material, a number of distinctive spores were seen at the bed, as they are utilizing raw material as a carbon source (Fig. 2).

\subsection{Optimization of physical and chemical parameters for cellulase production by Aspergillus niger}

To resolve the much operative and best conditions of process parameters, statistical optimization methodology has been used. Design based optimization for bioprocess could overcome the constraints of conventional methods and has been proved to be a dominant approach for the optimization of cellulase production. The present section evaluates the Box-Behnken based design experiments for cellulase production by $A$. niger. Temperature, $\mathrm{pH}$, initial moisture percentage of the substrate, inoculum dosages of fungal strains, raw materials particle size, incubation time were recognized as the most influential physical and chemical parameters. A Box-Behnken design was used to explore the interactive effect of these parameters and to attain an optimum. The base points for the design were selected from a single parameter study (data not shown). A summary of the variables and their variation levels is given in Tables 1 and 2 .

Various sets of combinations have been used for cellulase production by $A$. niger. It was observed in Table 3 as well as Figs. 3 and 4 that temperature $\left(30^{\circ} \mathrm{C}\right), \mathrm{pH}(5)$
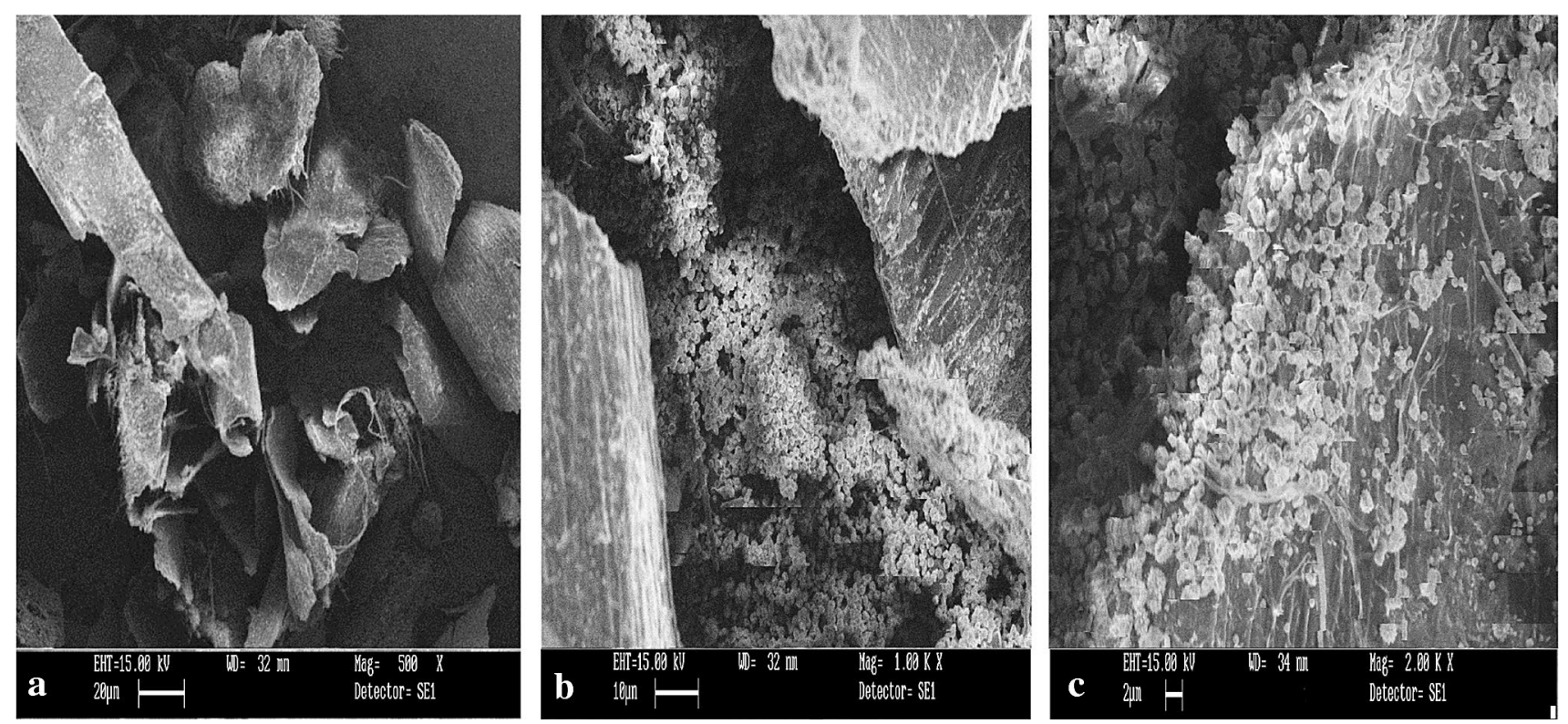

Fig. 2 Scanning electron micrograph (SEM) of Aspergillus treated wheat bran bed at $\times 500$ magnification (a), at $\times 1000$ (b), at $\times 2000$ (c)

\section{SN Applied Sciences}


Table 1 Variables used in Box-Behnken design for the optimization of process parameters such as temperature, $\mathrm{pH}$ and inoculum dosages

\begin{tabular}{lllll}
\hline Factor & Basic level & $\begin{array}{l}\text { Variation } \\
\text { interval }\end{array}$ & $\begin{array}{l}\text { Value } \\
\text { of the } \\
\text { factor }\end{array}$ & Coded value \\
\hline Temperature $\left({ }^{\circ} \mathrm{C}\right)$ & 30 & 5 & 25 & - \\
& & & 30 & 0 \\
& & & 35 & + \\
$\mathrm{pH}$ & 5 & 2 & 3 & - \\
& & & 5 & 0 \\
Inoculum dosages & 0.56 & 0.24 & 7 & + \\
& & & 0.32 & - \\
& & & 0.56 & 0 \\
& & & 0.80 & + \\
\hline
\end{tabular}

Table 2 Variables used in Box-Behnken design for the optimization of process parameters such as particle size, moisture percentage and incubation period

\begin{tabular}{lcccc}
\hline Factor & $\begin{array}{c}\text { Basic level } \\
\text { Vari- } \\
\text { ation } \\
\text { interval }\end{array}$ & $\begin{array}{l}\text { Value } \\
\text { of the } \\
\text { factor }\end{array}$ & Coded value \\
\hline Particle size $(\mu \mathrm{m})$ & 850 & 400 & 450 & - \\
& & & 850 & 0 \\
& & 5 & 7250 & + \\
Moisture percent- & 76 & 5 & 76 & - \\
$\begin{array}{l}\text { age (\%) } \\
\text { Incubation period }\end{array}$ & 6 & 3 & 81 & + \\
(days) & & & 3 & - \\
& & & 6 & 0 \\
& & & 9 & + \\
\hline
\end{tabular}

and inoculum dosages $(0.56 \mathrm{~g} / \mathrm{L})$ was found a quite operative set of combinations for cellulase activity ( $0.980 \mathrm{IU} /$ $\mathrm{mL}$ ) produced by $A$. niger as compared to other sets of combinations.

As observed in Fig. 3 that higher cellulase activity region lies in the center of the graph represents significantly better optimization of process parameters.

It was also observed in Fig. 4 that the rate of decrement in enzyme activity was somewhat lower towards $\left(>\right.$ and $\left.<30^{\circ} \mathrm{C}\right), \mathrm{pH}(<5)$ and inoculum dosages ( $>$ and $<0.56 \mathrm{~g} / \mathrm{L}$ ).

The experimental and predicted values of cellulase activity (FPA) are somehow nearly closer to each other which represents the nearly good correlation as observed from Table 3 and Fig. 5).

Distinctive sets of permutation have been used for cellulase production by $A$. niger. It was observed from Table 4 and Fig. 6 that particle size $(850 \mu \mathrm{m})$, moisture $(76 \%)$, and incubation period ( 6 days) was found a quite efficient set of combinations for cellulase activity $(1.29 \mathrm{lU} / \mathrm{mL})$ produced by A. niger as compared to other.

As observed in Fig. 6 that the higher cellulase activity region lies in the center of the graph which proves the significantly better optimization of process parameters.

It was also observed from Fig. 7 that rate of decrement in enzyme activity was somewhat lower towards smaller particle size $(<850 \mu \mathrm{m})$, higher moisture percentage $(>76)$ and higher incubation period ( $>6$ days).

The observed and predicted values of cellulase activity are extremely close to each other which signifies the very fine correlation between them as observed from Table 4 and Fig. 8. In each sets total of 10 coefficients are generated as observed from Table 5 .

It can be concluded that optimization was found quite effective, as well as in most of the cases experimental and
Table 3 Comparative experimental and predicted values of cellulase (FPA) activity $(\mathrm{IU} / \mathrm{mL})$ achieved by Aspergillus under different sets of combinations

\begin{tabular}{lllllrrrc}
\hline $\begin{array}{l}\text { Medium } \\
\text { code }\end{array}$ & $\mathrm{T}\left({ }^{\circ} \mathrm{C}\right)$ & $\mathrm{pH}$ & $\begin{array}{l}\text { Inoculum } \\
\text { dosages }\end{array}$ & $\mathrm{FPA}(\mathrm{IU} / \mathrm{mL})(\mathrm{E})$ & $\mathrm{T}\left({ }^{\circ} \mathrm{C}\right)$ & $\mathrm{pH}$ & $\begin{array}{l}\text { Inoculum } \\
\text { dosages }\end{array}$ & $\mathrm{FPA}(\mathrm{IU} / \mathrm{mL})(\mathrm{P})$ \\
\hline $\mathrm{A}$ & 25 & 3 & 0.56 & 0.518 & -1 & -1 & 0 & 0.345249 \\
$\mathrm{~B}$ & 25 & 5 & 0.32 & 0.646 & -1 & 0 & -1 & 0.79221 \\
$\mathrm{C}$ & 25 & 5 & 0.80 & 0.578 & -1 & 0 & 1 & 0.136993 \\
$\mathrm{D}$ & 25 & 7 & 0.56 & 0.442 & -1 & 1 & 0 & 0.400984 \\
$\mathrm{E}$ & 30 & 3 & 0.32 & 0.622 & 0 & -1 & -1 & 0.613322 \\
$\mathrm{~F}$ & 30 & 3 & 0.80 & 0.554 & 0 & -1 & 1 & -0.12464 \\
$\mathrm{G}$ & 30 & 5 & 0.56 & 0.980 & 0 & 0 & 0 & 0.695444 \\
$\mathrm{H}$ & 30 & 7 & 0.32 & 0.583 & 0 & 1 & -1 & 0.639056 \\
$\mathrm{I}$ & 30 & 7 & 0.80 & 0.476 & 0 & 1 & 1 & -0.0309 \\
$\mathrm{~J}$ & 35 & 3 & 0.56 & 0.578 & 1 & -1 & 0 & 0.049683 \\
$\mathrm{~K}$ & 35 & 5 & 0.32 & 0.544 & 1 & 0 & -1 & 0.549388 \\
$\mathrm{~L}$ & 35 & 5 & 0.80 & 0.646 & 1 & 0 & 1 & -0.20332 \\
$\mathrm{M}$ & 35 & 7 & 0.56 & 0.510 & 1 & 1 & 0 & 0.113418 \\
\hline
\end{tabular}

$T$ temperature $\left({ }^{\circ} \mathrm{C}\right), E$ experimental, $P$ predicted 
Fig. 3 Quadratic response surface model with cellulase activity $(\mathrm{IU} / \mathrm{mL})$ attained by Aspergillus as a response of three parameters temperature, $\mathrm{pH}$ and inoculum dosage. Cellulase dosage represents the cellulase activity $(\mathrm{IU} / \mathrm{mL})$
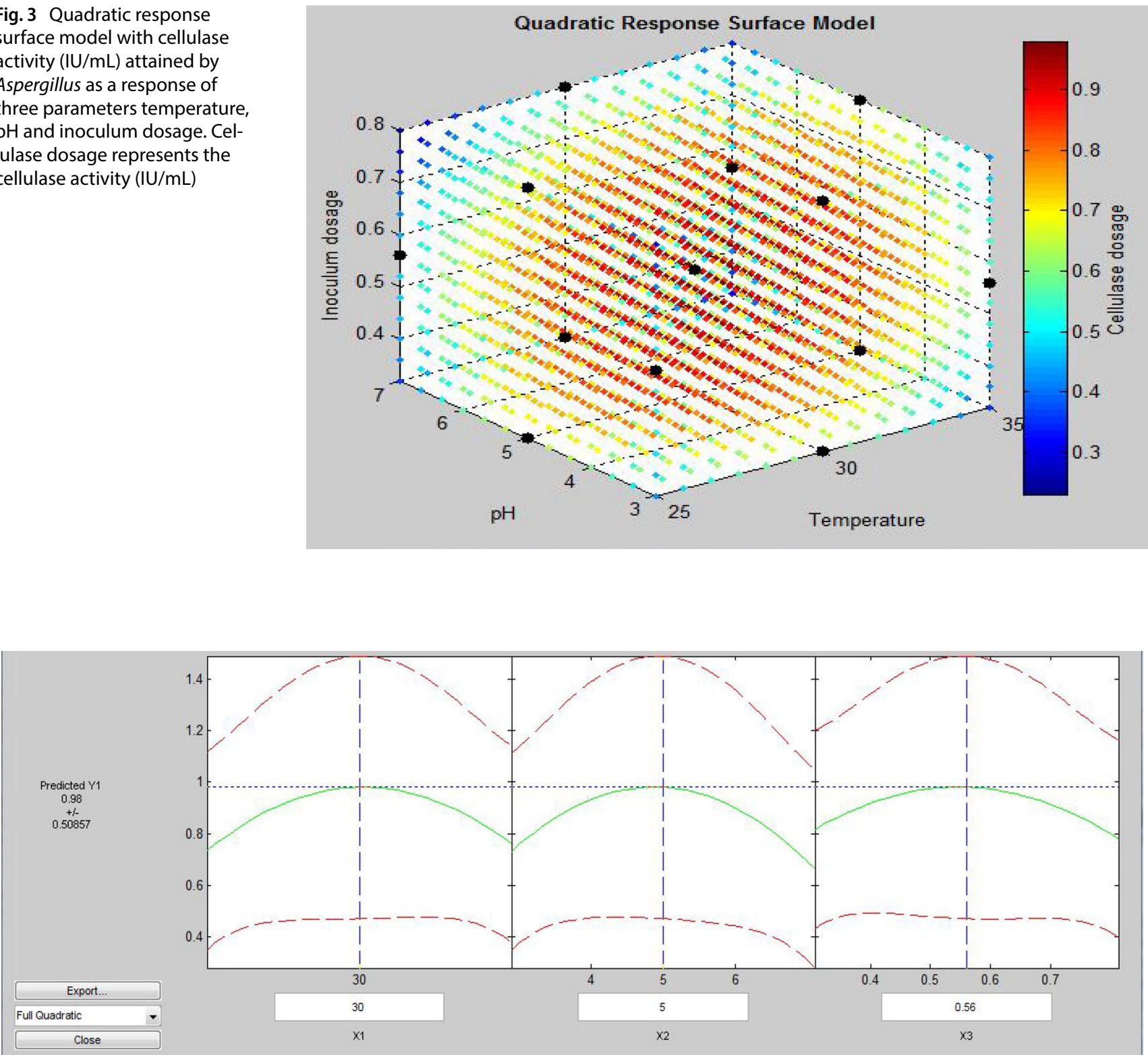

Fig. 4 Cellulase activity achieved by Aspergillus as a response (Y1) of three parameters temperature (X1), $\mathrm{pH}(\mathrm{X} 2)$ and inoculum dosage (X3)

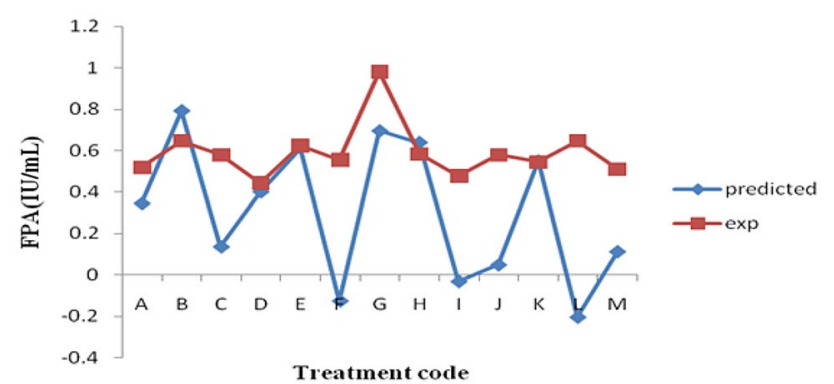

Fig. 5 Comparative graph of experimental and predicted values of cellulase activity (FPA) predicted values were very close to each other, representing the better correlation between them.

\subsection{Effect of dairy waste (whey) on cellulase production under wheat bran based solid-state fermentation}

To investigate the effect of dairy waste whey on cellulase production under wheat bran based solid-state fermentation, a separate set of experiments have been performed using $15 \%, 30 \%$ and $50 \%(\mathrm{v} / \mathrm{v})$ whey as carbon source. 
Table 4 Comparative experimental and predicted values of cellulase activity (IU/mL) attained by Aspergillus under a different sets of combinations

\begin{tabular}{|c|c|c|c|c|c|c|c|}
\hline Particle size & $\begin{array}{l}\text { Moisture per- } \\
\text { centage }\end{array}$ & $\begin{array}{l}\text { Incubation } \\
\text { period }\end{array}$ & FPA (IU/mL) (E) & Particle size & $\begin{array}{l}\text { Moisture per- } \\
\text { centage }\end{array}$ & $\begin{array}{l}\text { Incubation } \\
\text { period }\end{array}$ & $\mathrm{FPA}(\mathrm{IU} / \mathrm{mL})(\mathrm{P})$ \\
\hline 450 & 76 & 3 & 0.672 & -1 & 0 & -1 & 0.680729 \\
\hline 850 & 71 & 3 & 0.567 & 0 & -1 & -1 & 0.60796 \\
\hline 850 & 81 & 3 & 0.672 & 0 & 1 & -1 & 0.712898 \\
\hline 1250 & 76 & 3 & 0.567 & 1 & 0 & -1 & 0.647129 \\
\hline 450 & 71 & 6 & 0.735 & -1 & -1 & 0 & 0.75069 \\
\hline 450 & 81 & 6 & 0.840 & -1 & 1 & 0 & 0.855565 \\
\hline 850 & 76 & 6 & 1.290 & 0 & 0 & 0 & 1.333828 \\
\hline 1250 & 71 & 6 & 0.630 & 1 & -1 & 0 & 0.71709 \\
\hline 1250 & 81 & 6 & 0.735 & 1 & 1 & 0 & 0.821965 \\
\hline 450 & 76 & 9 & 0.798 & -1 & 0 & 1 & 0.815566 \\
\hline 850 & 71 & 9 & 0.696 & 0 & -1 & 1 & 0.74286 \\
\hline 850 & 81 & 9 & 0.801 & 0 & 1 & 1 & 0.847673 \\
\hline 1250 & 76 & 9 & 0.683 & 1 & 0 & 1 & 0.781966 \\
\hline
\end{tabular}

Fig.6 Quadratic response surface model with cellulase activity (FPA) attained by Aspergillus as a response of three parameters temperature, $\mathrm{pH}$ and inoculum dosage. Cellulase dosage represents the cellulase activity $(\mathrm{IU} / \mathrm{mL})$

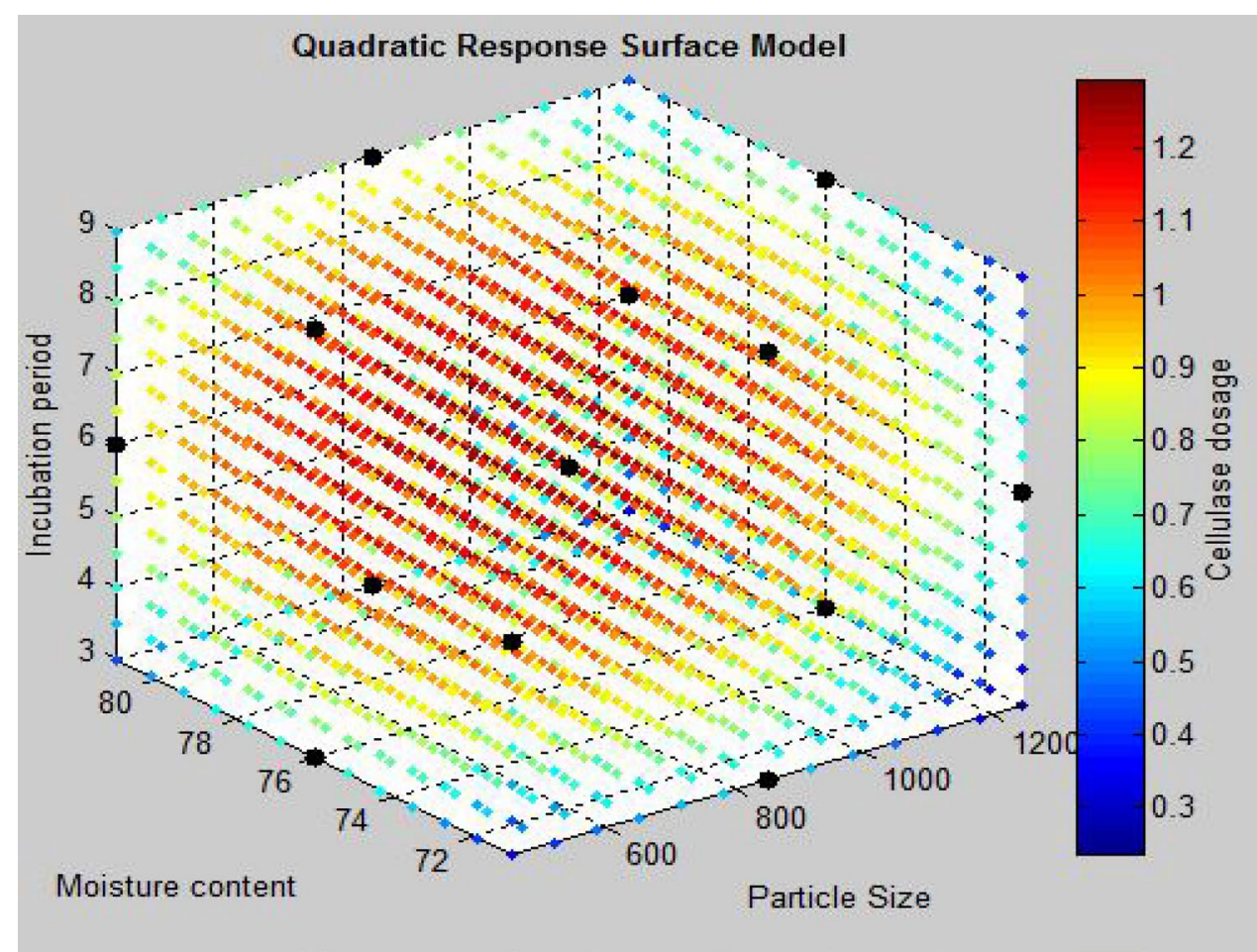

It has been observed in Table 6 that Aspergillus strain showed better activity under $30 \%$ whey containing wheat bran as compared to other dosages of whey. The maximum cellulase activities (IU/mL) in terms of FPA and CMCase attained by $A$. niger were $1.47 \pm 0.08$ and $11.02 \pm 0.05$ under $30 \%$ whey containing wheat bran based solid-state fermentation. Lactose sugars present in the whey may provide a favorable conditions for better cellulase activity for Aspergillus strain [29].

\subsection{Effect of starch hydrolysates on cellulase production under wheat bran based solid-state fermentation}

To examine the role of starch hydrolysates in cellulase production under wheat bran based solid-state fermentation, a separate set of experiments were executed. Starch pretreatments were performed by using 2 and $5 \%$ $\mathrm{HCl}$ with the pretreatment time of $1 \mathrm{~h}$. Maximum cellulase 


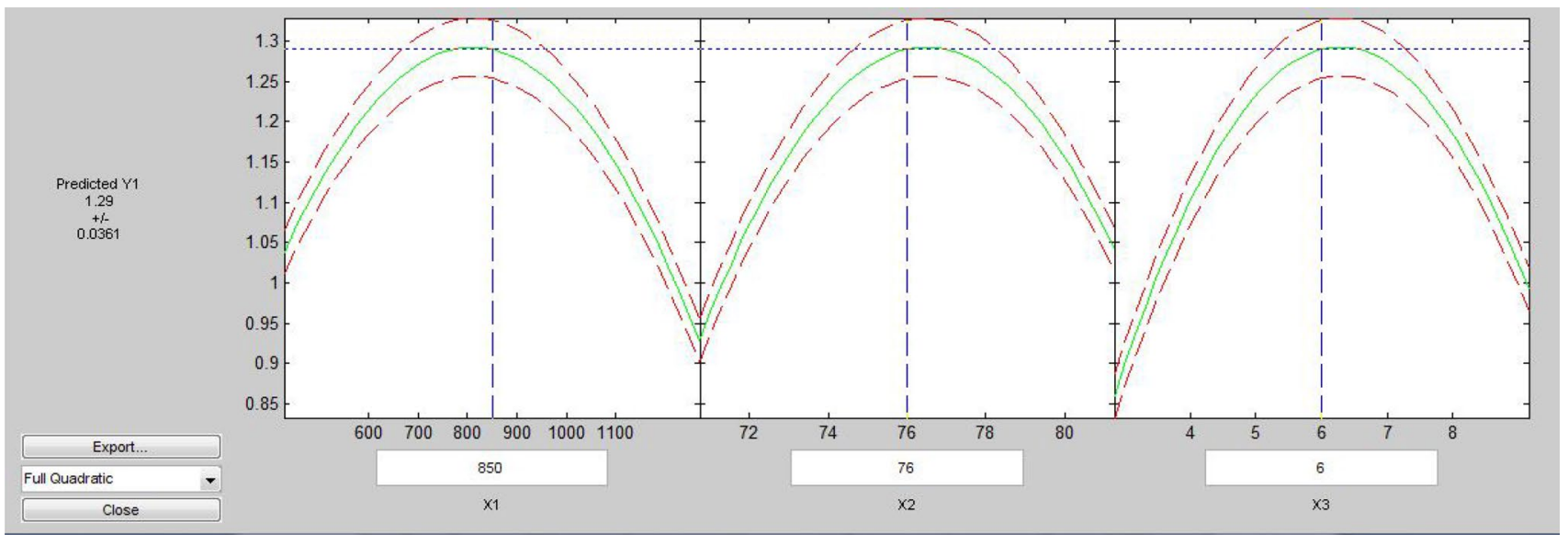

Fig. 7 Cellulase activity achieved by Aspergillus as a response (Y1) of three parameters particle size (X1), moisture percentage (X2) and incubation period (X3)

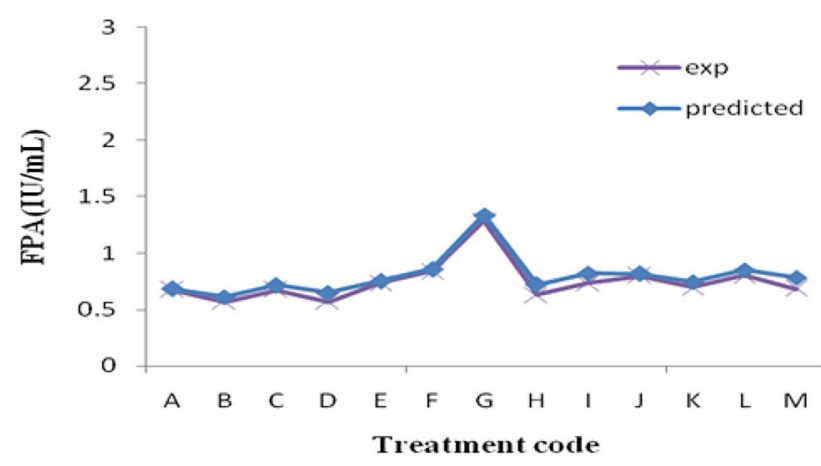

Fig. 8 Comparative graph of experimental and predicted values of cellulase activity (FPA)

Table 5 Coefficient values under different sets of condition

\begin{tabular}{ll}
\hline Aspergillus niger & \\
\hline Trail 1 & Trail 2 \\
\hline Temp, pH, inoculum dosages & $\begin{array}{l}\text { Particle size, moisture } \\
\text { percentage, incubation } \\
\text { period }\end{array}$ \\
& Coefficients \\
Coefficients & -65.765 \\
-8.51818 & 0.002848 \\
0.489417 & 1.68554 \\
0.63000 & 0.463271 \\
2.171528 & $-5.14 \mathrm{E}-19$ \\
0.0002 & $-2.08 \mathrm{E}-06$ \\
0.035417 & $-1.61 \mathrm{E}-16$ \\
-0.02031 & $-1.75 \mathrm{E}-06$ \\
-0.00847 & -0.01102 \\
-0.06409 & -0.03672 \\
-2.86241 & \\
\hline
\end{tabular}

Table 6 Comparative cellulase activity (IU/mL) achieved by Aspergillus strain under different concentrations of whey containing wheat bran based SSF at $30^{\circ} \mathrm{C}$ and $\mathrm{pH} 5$

\begin{tabular}{lll}
\hline Dairy industry waste (Whey) & \multicolumn{2}{l}{ Aspergillus niger } \\
\cline { 2 - 3 } & FPA (IU/mL) & CMCase (IU/mL) \\
\hline BSM + WB (without whey) & $1.29 \pm 0.03$ & $10.10 \pm 0.05$ \\
Whey & & \\
$15 \%(v / v)$ & $1.31 \pm 0.06$ & $10.53 \pm 0.03$ \\
$30 \%(v / v)$ & $1.47 \pm 0.08$ & $11.02 \pm 0.05$ \\
$50 \%(v / v)$ & $1.41 \pm 0.03$ & $10.62 \pm 0.09$ \\
\hline
\end{tabular}

Data are reported as mean \pm standard deviation based on the repeated trails

$B S M$ basal salt media, WB wheat bran

activities (IU/mL) in terms of FPA and CMCase attained by $A$. niger were $1.57 \pm 0.08$ and $12.45 \pm 0.06$ under $2 \%$ acid hydrolyzed rice starch hydrolysate $(5 \% \mathrm{v} / \mathrm{v})$ based solid- state fermentation, which may be due to release of some dimeric sugars such as cellobiose and sophorose in the acid hydrolysates starches. Cellobiose response regulator (ClbR) of Aspergillus aculeatus has been confirmed to accelerate the expression of cellulases [30]. It was also observed from Table 7 that fungal strains produce significantly higher cellulase activities under $2 \% \mathrm{HCl}$ treated wheat starch hydrolysate based fermentation medium as compared to $5 \% \mathrm{HCl}$ treated one, which may be due to the fact that upon under higher strength-based acid treatment, starch is over hydrolyzed and other byproducts may be generated, which might have served as inhibitors for cellulase production [31].

When compared the effectiveness of starch hydrolysates for Aspergillus strain than it has been observed that $A$. niger performed better under rice hydrolysate 
Table 7 Comparative cellulase activities (IU/mL) achieved by Aspergillus strain under various starch hydrolysates incorporated wheat bran based SSF at $30^{\circ} \mathrm{C}$ and $\mathrm{pH} 5$

\begin{tabular}{lll}
\hline Starch hydrolysates $(\mathrm{SH})$ & \multicolumn{2}{l}{ Aspergillus niger } \\
\cline { 2 - 3 } & FPA (IU/mL) & CMCase $(\mathrm{IU} / \mathrm{mL})$ \\
\hline $\mathrm{BSM}+\mathrm{WB}$ (without SH) & $1.29 \pm 0.03$ & $10.10 \pm 0.05$ \\
$2 \% \mathrm{HCl} \mathrm{WSH}$ & & \\
$2 \%(\mathrm{v} / \mathrm{v})$ & $1.41 \pm 0.03$ & $11.17 \pm 0.02$ \\
$5 \%(\mathrm{v} / \mathrm{v})$ & $1.53 \pm 0.06$ & $11.87 \pm 0.07$ \\
$5 \% \mathrm{HCl} \mathrm{WSH}$ & & \\
$2 \%(\mathrm{v} / \mathrm{v})$ & $1.20 \pm 0.11$ & $9.70 \pm 0.05$ \\
$5 \%(\mathrm{v} / \mathrm{v})$ & $1.18 \pm 0.02$ & $9.51 \pm 0.13$ \\
$2 \% \mathrm{HCl} \mathrm{PSH}$ & & \\
$2 \%(\mathrm{v} / \mathrm{v})$ & $1.38 \pm 0.09$ & $10.70 \pm 0.09$ \\
$5 \%(\mathrm{v} / \mathrm{v})$ & $1.41 \pm 0.03$ & $11.21 \pm 0.11$ \\
$5 \% \mathrm{HCl}$ PSH & & \\
$2 \%(\mathrm{v} / \mathrm{v})$ & $1.16 \pm 0.07$ & $9.32 \pm 0.05$ \\
$5 \%(\mathrm{v} / \mathrm{v})$ & $1.13 \pm 0.02$ & $9.21 \pm 0.03$ \\
$2 \% \mathrm{HCl}$ RSH & & \\
$2 \%(\mathrm{v} / \mathrm{v})$ & $1.43 \pm 0.13$ & $11.59 \pm 0.09$ \\
$5 \%(\mathrm{v} / \mathrm{v})$ & $1.57 \pm 0.08$ & $12.45 \pm 0.06$ \\
$5 \% \mathrm{HCl} \mathrm{RSH}$ & & $9.83 \pm 0.03$ \\
$2 \%(\mathrm{v} / \mathrm{v})$ & $1.22 \pm 0.04$ & $9.67 \pm 0.07$ \\
$5 \%(\mathrm{v} / \mathrm{v})$ & $1.20 \pm 0.03$ & \\
\hline
\end{tabular}

Data are reported as mean \pm standard deviation based on the repeated trails

WSH wheat starch hydrolysate, $P S H$ potato starch hydrolysate, $R S H$ rice starch hydrolysate

containing wheat bran based fermentation. Potato starch hydrolysate was found less effective for cellulase activity enhancement as compared to wheat starch. It can be concluded that rice, as well as wheat starch hydrolysate, were found quite effective for cellulase induction capability. The acid hydrolysis of starch considerably changes the structural and functional properties of starch. Amorphous regions are hydrolyzed favorably during acid hydrolysis [32].

When compared to the induction capabilities of whey and starch hydrolysates perceived from Tables 6 and 7. It has been observed from experimental evidence that starch hydrolysate has a better ability for induction as compared to whey. This advocate that oligosaccharides and dimeric sugars provoke much better cellulase production as compared to lactose by $A$. niger. We can also suggest that raw material composition also affects the performance of starch hydrolysates.

\section{Conclusions}

Utilizing lignocellulosic waste materials as agricultural residues, forestry wastes and other low-cost biomass can significantly reduce the cost of production. In the present investigation, Box-Behnken design was used to optimize the process parameters for cellulase production by $A$. niger under wheat bran based solid-state cultivation. It is an applicable and trustworthy tool for finding the optimal process parameters. Various starch hydrolysates, as well as dairy industry waste (whey), were used in cellulase production. Higher cellulase activity attained by $A$. niger under $30 \%(\mathrm{v} / \mathrm{v})$ whey as well as $5 \%(\mathrm{v} / \mathrm{v})$ of $2 \% \mathrm{HCl}$ treated potato starch containing media. The utilization of waste materials in cellulase production would be a cost-effective, efficient, environment-friendly and sustainable approach.

Acknowledgements Authors gratefully acknowledged the support and facilities provided by Indian Institute of Technology, Roorkee, India for scanning electron microscopic (SEM) and other analysis. They also acknowledged the Ministry of human resource and development (MHRD) India, for providing fellowship to carry out present research work.

\section{Compliance with ethical standards}

Conflict of interest The authors declare that they have no conflict of interest.

\section{References}

1. Qian EW (2014) Research approaches to sustainable biomass systems. In: Tojo S, Hirasawa T (eds) Pretreatment and saccharification of lignocellulosic biomass. Academic Press, Cambridge, pp 181-204

2. Den W, Sharma VK, Lee M, Nadadur G, Rajender S, Varma RS (2018) Lignocellulosic biomass transformations via greener oxidative pretreatment processes: access to energy and valueadded chemicals. Front Chem 6:141

3. Sun X, Liu Z, Qu Y, Li X (2008) The effects of wheat bran composition on the production of biomass-hydrolyzing enzymes by Penicillium decumbens. Appl Biochem Biotechnol 146(1-3):119-128

4. Verma N, Bansal MC, Kumar V (2011) Pea peel waste: a lignocellulosic waste and its utility in cellulase production by Trichoderma reesei under solid state cultivation. Bioresources 6(2):1505-1519

5. Jena H, Halder SK, Soren JP, Takó M, Mondal KC (2016) Valorization of wheat bran for cost-effective production of cellulolytic enzymes by Aspergillus fumigatus SKH2 and utilization of the enzyme cocktail for saccharification of lignocellulosic biomass. Acta Biol 60(2):129-137

6. Verma N, KumarV Bansal MC (2018) Utility of Luffa cylindrica and Litchi chinensis peel, an agricultural waste biomass in cellulase production by Trichoderma reesei under solid state cultivation. Biocatal Agric Biotechnol 16:483-492

7. Ishizaki H, Hasumi K (2014) Research approaches to sustainable biomass systems. In: Tojo S, Hirasawa T (eds) Ethanol production from biomass. Academic Press, Cambridge, pp 243-258 
8. Fatima S, Hameed A, Noman M, Ahmed T, Shahid M, Tariq M, Sohail I, Tabassum R (2018) Lignocellulosic biomass: a sustainable bioenergy source for the future. Protein Pept Lett 25(2):148-163

9. Bergmans MEF, Beldman G, Gruppen H, Voragen AGJ (1996) Optimisation of the selective extraction of (glucurono) arabinoxylans from wheat bran: use of barium and calcium hydroxide solution at elevated temperatures. J Cereal Sci 23:235-245

10. Dervilly G, Saulnier L, Roger P, Thibault JF (2000) Isolation of homogeneous fractions from wheat water-soluble arabinoxylans Influence of the structure on their macromolecular characteristics. J Agric Food Chem 48:270-278

11. Merali Z, Collins SRA, Elliston A, Wilson DR, Käsper A, Waldron KW (2015) Characterization of cell wall components of wheat bran following hydrothermal pretreatment and fractionation. Biotechnol Biofuels 8:23

12. Das A, Paul T, Jana A, Halder SK, Ghosh K, Maity C, Das Mohapatra PK, Pati BR, Mondal KC (2013) Bioconversion of rice straw to sugar using multizyme complex of fungal origin and subsequent production of bioethanol by mixed fermentation of Saccharomyces cerevisiae MTCC 173 and Zymomonas mobilis MTCC 2428. Ind Crops Prod 46:217-225

13. Sharma D, Garlapat VK, Gunjan Goel G (2016) Bioprocessing of wheat bran for the production of lignocellulolytic enzyme cocktail by Cotylidia pannosa under submerged conditions. Bioengineered 7(2):88-97

14. Tabssum F, Irfan M, Shakir HA, Qazi Jl (2018) RSM based optimization of nutritional conditions for cellulase mediated Saccharification by Bacillus cereus. J Biol Eng 12:7

15. Mandal M, Ghosh U (2018) Application of statistical tool for optimization of physical parameters for cellulase production under solid state fermentation. Ind J Biotechnol 17:441-447

16. Kavitha S, Sivamani S (2016) Statistical optimization of cellulase production from cassava stem by Cellulomonas fimi MTCC24 using Box-Behnken design. J Pharm Chem Biol Sci 4(3):375

17. Mohammad SF, Feng Y, Yang G (2019) Optimization of cell culture and cell disruption processes to enhance the production of thermophilic cellulase FnCel5A in E. coli using response surface methodology. PLoS ONE 14(1):e0210595

18. Gupta VK (2000) Overview of processing and utilization of dairy by products. Indian Dairym 52:55-59

19. Panesar PS, Kennedy JF, GandhiDN Bunko K (2007) Bioutilisation of whey for lactic acid production. Food Chem 105(1):1-14

20. Macwan SR, Dabhi BK, Parmar SC, Aparnathi KD (2016) Whey and its utilization. Int J Curr Microbiol Appl Sci 5(8):134
21. Carvalho AJF (2013) Handbook of biopolymers and biodegradable plastics. Starch: major sources, properties and applications as thermoplastic materials. Elsevier, Amsterdam, pp 129-152

22. Triyono A, Andriansyah RCE, Luthfiyanti R, Rahman T (2017) Development of modified starch technology (maltodextrin) from commercial tapioca on semi production scale using oil heater dextrinator. Conference series: earth and environmental science. IOP Publishing, Bristol, p 101

23. Singh J, Kaur L, McCarthy OJ (2009) Advances in potato chemistry and technology. Potato starch and its modification. Academic Press, Cambridge, pp 273-318

24. Nebesny E, Rosicka J, Tkaczyk M (2000) Optimisation of physical and chemical properties of wheat starch hydrolyzates. Prog Biotechnol 17:201-208

25. Nickerson TA, Vujicic IF, Lin AY (1976) Colorimetric estimation of lactose and its hydrolytic products. J Dairy Sci 59(3):386-390

26. Domingues FC, Queinoz JA, Cabral JMS, Fonseca LP (2004) The influence of culture conditions on mycelial structure and cellulase production by Trichoderma reesei RUT C 30. Enzyme Microb Technol 26:394

27. Ghose TK (1987) Measurement of cellulase activities. Pure Appl Chem 59(2):257-268

28. Verma N, Kumar V, Bansal MC (2012) Utilisation of egg shell waste in cellulase production by Neurospora crassa under wheat bran based solid state cultivation. Pol J Environ Stud 21(2):491-497

29. Akula S, Golla N (2018) Optimization of cellulase production by Aspergillus niger isolated from forest soil. Open Biotechnol J 13:256-269

30. Zhang Y, Tang B, Du G (2017) Self-induction system for cellulase production by cellobiose produced from glucose in Rhizopus stolonifer. Sci Rep 7:10161

31. Wang S, Copeland L (2015) Effect of acid hydrolysis on starch structure and functionally: a review. Crit Rev Food Sci Nutr 55(8):1081-1097

32. Chen S, Wayman M (1992) Novel inducers derived from starch for cellulase production by Trichoderma reesei. Process Biochem 27:327-334

Publisher's Note Springer Nature remains neutral with regard to jurisdictional claims in published maps and institutional affiliations. 